\title{
Adaptation of Glucose-grown Saccharomyces cerevisiae to Gluconeogenic Growth and Sporulation
}

\author{
By MARTHA I. CHU, ANDREAS HARTIG, ELISABETH B. FREESE* \\ AND ERNST FREESE \\ Laboratory of Molecular Biology, National Institute of Neurological and Communicative \\ Disorders and Stroke, Bethesda, Maryland 20205, U.S.A.
}

(Received 14 October 1980; revised 12 January 1981)

\begin{abstract}
When cells of Saccharomyces cerevisiae growing exponentially on D-glucose as sole carbon source were washed and transferred to buffered yeast nitrogen base containing $100 \mathrm{~mm}$-acetate, they were unable to resume growth for several days whereas they adapted within a few hours to grow (slowly) on ethanol, and within $12 \mathrm{~h}$ to grow on pyruvate. After the cell transfer, oxygen consumption and ATP concentration decreased rapidly but recovered within a few hours on ethanol, more slowly on pyruvate, and only after $70 \mathrm{~h}$ on acetate. When the acetate culture had lost all detectable ATP, the viable cell titre slowly decreased until after $70 \mathrm{~h}$ enough cells had adapted to resume growth. At lower acetate concentrations (optimally 5 to $15 \mathrm{mM}$ ), ATP decreased less, and growth resumed within $1 \mathrm{~d}$. After transfer from glucose medium to buffer plus a carbon source, cells sporulated equally well at ethanol concentrations from 20 to $150 \mathrm{mM}$ and at $\mathrm{pH} 5.5$ or 7.0 ; with dihydroxyacetone, another uncharged carbon source, sporulation was optimal at concentrations between 30 and $50 \mathrm{mM}$ and about equal at pH 5.5 and 7.0. In contrast, after transfer from glucose medium to buffer plus acetate, cells sporulated at pH 5.5 optimally with $15 \mathrm{mM}$ acetate but not with $50 \mathrm{mM}$-acetate or more; at $\mathrm{pH} 7.0$ sporulation showed a broader optimum of acetate concentration around $50 \mathrm{mM}$. The results indicated that in cells not adapted to gluconeogenesis, high concentrations of neutral acetic acid molecules caused complete consumption of intracellular ATP; consequently the cells could not adapt to gluconeogenesis for a long time.
\end{abstract}

\section{INTRODUCTION}

Wild-type strains of Saccharomyces cerevisiae can grow on acetate, ethanol, D-glucose and other compounds as sole carbon source. In a glucose-containing growth medium, they undergo diauxic growth (Maxon \& Johnson, 1953; Polakis \& Bartley, 1965; Haarasilta \& Oura, 1975). Initially, cells grow at a high rate on glucose, and ethanol, acetaldehyde (which evaporates) and acetate accumulate in the medium. When most of the glucose has been used up, they enter a stationary phase during which they adapt to use the products of sugar metabolism. A few hours later, they resume growth at a low rate. During the adaptation a number of previously repressed gluconeogenic enzymes are synthesized, e.g. isocitrate lyase, malate synthase, one of the two malate dehydrogenases, phosphoenolpyruvate carboxykinase and fructose-bisphosphatase (Polakis \& Bartley, 1965; Duntze et al., 1967; Haarasilta \& Oura, 1975). Because ethanol has to be metabolized to acetate before it can be used as a gluconeogenic carbon source, one might expect that cells growing exponentially on glucose would adapt at least as rapidly after transfer to a growth medium containing $(100 \mathrm{mM})$ acetate as to one containing ethanol as sole carbon source. In fact, cells need many more days to adapt to acetate than to ethanol. In this paper we explain this phen- 
omenon by showing that ethanol maintains the energization (ATP) of the cell whereas acetate (at high concentrations) destroys it.

The same problem of adapting to acetate as carbon source is encountered during yeast sporulation. When diploid cells of $S$. cerevisiae are transferred from a growth medium containing acetate (but no glucose) to $100 \mathrm{~mm}$-potassium acetate as sporulation medium, they soon enter meiosis and sporulate within $20 \mathrm{~h}$ (Roth \& Halvorson, 1969; Fast, 1973). But if cells growing exponentially in a glucose-containing medium are washed and transferred to potassium acetate, it takes several days before some sporulate. To obtain good sporulation using glucose media, cells are therefore transferred to potassium acetate only after they have used up all glucose (Croes, 1967; Fast, 1973). Apparently, yeast can readily sporulate on acetate only if the cells are already adapted to use it as carbon source for energy generation and for gluconeogenesis. As mentioned above, the adaptation of glucose-grown cells to acetate is delayed by the destruction of the remaining metabolic energy (ATP) by reaction with acetate. This delay should be reduced if fewer acetate molecules entered the cells. Therefore, we have examined the ability of glucose-grown cells to sporulate after cell transfer to different concentrations of acetate, ethanol or dihydroxyacetone in buffer at different $\mathrm{pH}$ values. A change of $\mathrm{pH}$ should significantly change the concentration of neutral acetic acid molecules (the species which preferentially enters cells), whereas it should not affect the concentration of the neutral ethanol or dihydroxyacetone molecules. Dihydroxyacetone was used for comparison because it is slowly metabolized, supports sporulation (Miller, 1957; Miller \& Hoffmann-Ostenhof, 1964) and has to be phosphorylated (just as acetate has to be converted to acetyl-CoA) before it can be used as a metabolite in the Embden-Meyerhof pathway.

\section{METHODS}

Strain and media. Homothallic Saccharomyces cerevisiae strain Y 55 was obtained from Dr H. O. Halvorson. Cells were kept frozen in $25 \%$ glycerol and pregrown on plates containing $1 \%(\mathrm{w} / \mathrm{v})$ yeast extract, $2 \%(\mathrm{w} / \mathrm{v})$ peptone and $1 \%(\mathrm{w} / \mathrm{v})$ glucose (YEP + glucose; Roth \& Halvorson, 1969). The basic medium (MN) contained $100 \mathrm{mM}-2$ - $(N$-morpholino)ethanesulphonic acid (MES), adjusted to $\mathrm{pH} 5.5$ by $\mathrm{KOH}$, and $0.67 \%(\mathrm{w} / \mathrm{v})$ Difco yeast nitrogen base without amino acids. Carbon sources were added as stated; all acids were adjusted to $\mathrm{pH} 5.5$ by $\mathrm{KOH}$.

Growth conditions. Cells were inoculated into $\mathrm{MN}+100 \mathrm{mM}$ carbon sources, such as glucose, fructose, potassium pyruvate, potassium acetate, ethanol, dihydroxyacetone, etc., to give an $A_{600}$ of $0 \cdot 1$. After $8 \mathrm{~h}$ at $30^{\circ} \mathrm{C}$ the cells were collected on a membrane filter $(0.45 \mu \mathrm{m}$ pore size $)$, washed twice with the same medium and suspended to an $A_{600}$ of 0.05 , with the exception of the cultures containing glucose and fructose in which cells were suspended to an $A_{600}$ of 0.001 . After $16 \mathrm{~h}$ at $30^{\circ} \mathrm{C}$ the cells were again collected on a membrane filter, washed twice and suspended to an $A_{600}$ of 0.1 in the same medium. Growth was then followed by measuring the $A_{600}$ in a Zeiss PMQII spectrophotometer; where necessary, the sample was diluted in water to obtain an $A_{600}$ of less than 0.8 . At stated times, samples were taken to count the number of cells $\mathrm{ml}^{-1}$ and the frequency of asci (using a phase-contrast microscope). In determining the number of asci per cell, 400 to 1000 cells (buds included as cells) were evaluated for each sample. The viable cell titre was measured by diluting the culture in water and plating on YEP + glucose.

Sporulation conditions. Cells were grown in MN $+100 \mathrm{mM}$-glucose to an $A_{600}$ of 1 . They were collected on a membrane filter $(0.45 \mu \mathrm{m}$ pore size), washed twice with $0.5 \mathrm{vol}$. buffer [MES, pH 5.5, or $N$-tris(hydroxymethyl)methyl-2-aminoethanesulphonate (TES), adjusted to $\mathrm{pH} 7.0$ by $\mathrm{KOH}$ and suspended in double-strength buffer. Samples $(5 \mathrm{ml})$ were distributed into $125 \mathrm{ml}$ prewarmed flasks to which the compound to be tested or distilled water had been added in $5 \mathrm{ml}$. The time of cell distribution was taken as time 0 . At stated times, the frequency of asci was determined as described above.

Preparation of extracts for enzyme assays. Cells were grown in $500 \mathrm{ml} \mathrm{MN}+100 \mathrm{mM}$ carbon source to an $A_{600}$ of 1 , harvested by centrifuging and washed twice with ice-cold extraction buffer $(50 \mathrm{mM}-\mathrm{Tris} / \mathrm{HCl}, 1 \mathrm{mM}$ EDTA, pH 7.4). They were suspended in twice their volume of extraction buffer (final vol. 2 to $4 \mathrm{ml}$ ) and ruptured by two passages through an ice-cold French press at $125 \mathrm{MPa}\left(18000 \mathrm{lbf} \mathrm{in}^{-2}\right)$. The homogenate was centrifuged at $20000 \mathrm{~g}$ for $10 \mathrm{~min}$ to remove unbroken cells and cell debris. Part of the supernatant solution was frozen in solid $\mathrm{CO}_{2}$ and kept at $-70^{\circ} \mathrm{C}$; another part was used immediately to measure alcohol dehydrogenase and acetyl-CoA synthetase activities. 
Enzyme assays. Fructose bisphosphatase (EC 3.1.3.11) was measured according to Foy \& Bhattacharjee (1977) except that $0.5 \mathrm{mM}^{-N A D P}{ }^{+}$was used. Pyruvate kinase (EC 2.7.1.40) was measured according to Aust \& Suelter (1978) except that $5 \mathrm{~mm}$-ADP and $0.2 \mathrm{~mm}$-NADH were used. Phosphoenolpyruvate carboxykinase (ATP) (EC 4.1.1.49) was measured according to Hansen et al. (1976), malate dehydrogenase (EC 1.1.1.37) according to Ferguson et al. (1967), isocitrate lyase (EC 4.1.3.1) according to Dixon \& Kornberg (1959), and alcohol dehydrogenase (EC 1.1.1.1) according to Racker (1950).

Malate synthase (EC 4.1.3.2) was measured according to Dixon \& Kornberg (1959). The mixture contained

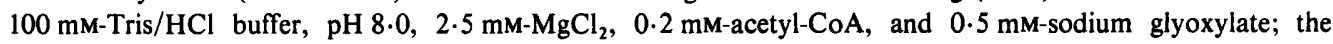
reaction was followed at $232 \mathrm{~nm}$.

Acetyl-CoA synthetase (EC 6.2.1.1) was measured as described by Berg (1956), except that the reaction mixture contained $10 \mathrm{mM}-\mathrm{MgCl}_{2}$ and $20 \mathrm{mM}$-potassium acetate, and the incubation time was $15 \mathrm{~min}$.

Aldehyde dehydrogenase $\left(\mathrm{NAD}(\mathrm{P})^{+}\right)(\mathrm{EC}$ 1.2.1.5) was determined essentially as described by Bostian \& Betts (1978). The reaction mixture contained $100 \mathrm{mM}$-Tris/ $\mathrm{HCl}$ buffer, $\mathrm{pH} 8.3,5 \mathrm{~mm}$-glutathione, $2 \mathrm{mM}$ $\mathrm{NAD}^{+}, 1 \mathrm{mM}$-acetaldehyde and $1 \mathrm{mM}-\mathrm{KCN}$ to prevent $\mathrm{NADH}$ oxidation by the crude extract.

Pyruvate carboxylase (EC 6.4.1.1) was measured essentially as described by Ruiz-Amil et al. (1965) and Diesterhaft \& Freese (1973). The reaction mixture contained $100 \mathrm{mM}$-Tris/HCl buffer, pH 7.6, $20 \mathrm{mM}-\mathrm{KH}^{14} \mathrm{CO}_{3}$ $\left(0.05 \mu \mathrm{Ci} \mu \mathrm{mol}^{-1}\right), \quad 10 \mathrm{~mm}-\mathrm{ATP}, \quad 10 \mathrm{~mm}-\mathrm{MgCl}_{2}, 0.1 \mathrm{~mm}$-acetyl-CoA, $20 \mathrm{~mm}$-sodium glutamate, $10 \mathrm{~mm}-$ potassium pyruvate and $6 \mathrm{U} \mathrm{ml}^{-1}$ glutamate-oxaloacetate transaminase (Boehringer). The reaction was started by addition of potassium pyruvate. After $20 \mathrm{~s}, 2 \mathrm{~min}$ and $5 \mathrm{~min}, 0.2 \mathrm{ml}$ of this reaction mixture was mixed with $0.1 \mathrm{ml}$ concentrated $\mathrm{HCl}$ and left standing at room temperature for at least $20 \mathrm{~min}$. The samples were then centrifuged for $10 \mathrm{~min}$ at $4000 \mathrm{~g}$ and $0.1 \mathrm{ml}$ of each supernatant was placed in a scintillation vial. After drying with a stream of $\mathrm{CO}_{2}, 0.5 \mathrm{ml}$ water and then $10 \mathrm{ml}$ Aquasol (New England Nuclear) were added. The radioactivity of the mixture was counted in a scintillation counter.

All specific activities were expressed as nmol $\min ^{-1}(\mathrm{mg} \text { protein })^{-1}$.

Preparation of extracts for ATP measurement. ATP was extracted in two ways. (1) $0.5 \mathrm{ml}$ culture was pipetted into $0.5 \mathrm{ml}$ ice-cold $0.5 \mathrm{M}$-formic acid containing $2 \mathrm{mM}$-EDTA. After mixing and standing on ice for $60 \mathrm{~min}$, the samples were frozen in solid $\mathrm{CO}_{2}$ and kept at $-70^{\circ} \mathrm{C}$. (2) $20 \mathrm{ml}$ culture was rapidly filtered through a Millipore filter $(1.2 \mu \mathrm{m}$ pore size, type RA). The filter membrane was placed upside down on $0.5 \mathrm{ml}$ ice-cold $0.5 \mathrm{M}$-formic acid containing $2 \mathrm{mM}$-EDTA held in the cap of a centrifuge tube. After mixing and standing on ice for $60 \mathrm{~min}$, the extract was centrifuged at low speed and kept frozen until used. ATP measurements were made with the luciferin-luciferase test method as described by Levin \& Freese (1977).

Other assays. Oxygen consumption was determined with an oxygen electrode (Gilson Instrument Co.) according to Kielley (1963) and Estabrook (1967). Pyruvate was determined according to Friedemann \& Hangen (1943), acetate according to Holz \& Bergmeyer (1974), and ethanol according to Witt (1974). To express the measured values per amount of cells, the dimensionless unit AM is used. One AM unit is that amount of cells which gives an $A_{600}$ of 1 if it is suspended in $1 \mathrm{ml}$. Because $A_{600}$ measures the turbidity of a culture, which depends on cell size and shape, AM is only approximately proportional to cell mass (or cell number).

\section{RES ULTS}

\section{Growth and enzyme repression in the presence of different carbon sources}

Strain Y55 grew at a high rate in synthetic medium $(\mathrm{MN})+100 \mathrm{~mm}$-glucose (Table 1) until the $A_{600}$ was 7.5 . Ethanol (maximally $160 \mathrm{mM}$ ) and later some acetate (maximally $20 \mathrm{~mm}$ ) accumulated until all glucose had disappeared. Subsequently, both fermentation products were slowly consumed while the $A_{600}$ increased slowly. Strain Y55 could also grow on acetate, ethanol, pyruvate and dihydroxyacetone with the doubling times shown in Table 1.

We measured the activities of various gluconeogenic enzymes in Y55 cells that had been adapted to grow in MN $+100 \mathrm{mM}$ of the different carbon sources (Table 2). Of all the carbon sources used, only glucose and fructose strongly repressed the synthesis of aldehyde dehydrogenase, fructose-bisphosphatase, isocitrate lyase, malate synthase and phosphoenolpyruvate carboxykinase. Significantly, acetyl-CoA synthetase was not repressed by glucose, and alcohol dehydrogenase was only partially repressed. This agrees with the reported finding of three alcohol dehydrogenases, one of which is repressed by glucose (Ciriacy, 1975). 


\section{Table 1. Doubling times and sporulation with different carbon sources}

To measure the doubling time, strain Y55 was grown for more than $24 \mathrm{~h}$ in $\mathrm{MN}+100 \mathrm{mM}$ of stated carbon source (acids were adjusted to $\mathrm{pH} 5.5$ by $\mathrm{KOH}$ ); when necessary, to maintain an $A_{600}$ of less than 1, the cells (collected on a membrane filter) were transferred to fresh medium. Pyruvate was used at $300 \mathrm{~mm}$ to avoid all sporulation. The doubling time with dihydroxyacetone plus $0.8 \mathrm{mM}-\mathrm{L}$ aspartate was $7.35 \mathrm{~h}$.

To measure sporulation, strain Y55 was grown in $\mathrm{MN}+100 \mathrm{mM}$-glucose to an $A_{600}$ of 1 , then washed with $\mathrm{M}$, and transferred (to give an $A_{600}$ of 1) to M plus $100 \mathrm{mM}$ of the stated carbon source (pH 5.5). The percentage of asci was determined 24,48 and $72 \mathrm{~h}$ after transfer. In all cultures, less than $0.2 \%$ of the cells had asci after $24 \mathrm{~h}$.

\begin{tabular}{|c|c|c|c|c|c|}
\hline \multirow[b]{2}{*}{ Carbon source } & \multirow[b]{2}{*}{$\begin{array}{l}\text { Doubling } \\
\text { time } \\
\text { (h) }\end{array}$} & \multicolumn{2}{|c|}{ Sporulation after $48 \mathrm{~h}$} & \multicolumn{2}{|c|}{ Sporulation after $72 \mathrm{~h}$} \\
\hline & & $\begin{array}{c}\text { Asci } \\
\text { per cell } \\
(\%)\end{array}$ & $\begin{array}{c}\text { Tetrads } \\
\text { per ascus } \\
(\%)\end{array}$ & $\begin{array}{c}\text { Asci } \\
\text { per cell } \\
(\%)\end{array}$ & $\begin{array}{c}\text { Tetrads } \\
\text { per ascus } \\
(\%)\end{array}$ \\
\hline Acetate & $3 \cdot 20$ & $<0.2$ & - & 2 & 100 \\
\hline Ethanol & 4.59 & 32 & 100 & 44 & 93 \\
\hline Dihydroxyacetone & $8 \cdot 56$ & 10 & 90 & 14 & 64 \\
\hline Glucose & 1.79 & 6 & 100 & 23 & 98 \\
\hline Pyruvate & $7 \cdot 20$ & 7 & 100 & 7 & 93 \\
\hline None & - & $<0.2$ & - & $<0.2$ & - \\
\hline
\end{tabular}

Table 2. Specific activities of some enzymes during growth on different carbon sources

Strain Y55 was grown in MN $+100 \mathrm{mM}$ of the stated carbon source. When the $A_{600}$ reached 1 , cells were harvested and extracted. The specific activities $\left[\mathrm{nmol} \mathrm{min}^{-1}\right.$ (mg protein) $\left.{ }^{-1}\right]$ of the extracts were determined as described in Methods. Each result is the average of measurements in two or more extracts.

\begin{tabular}{|c|c|c|c|c|c|c|}
\hline Enzyme & Glucose & Fructose & $\begin{array}{c}\text { Dihydroxy- } \\
\text { acetone }\end{array}$ & Pyruvate & Ethanol & Acetate \\
\hline Acetyl-CoA synthetase & 0.07 & - & - & - & $0 \cdot 15$ & $0 \cdot 19$ \\
\hline Alcohol dehydrogenase & 0.24 & 0.26 & $2 \cdot 78$ & 1.98 & $1 \cdot 15$ & 0.49 \\
\hline Aldehyde dehydrogenase & $<0.0004$ & $<0.0004$ & 0.016 & 0.049 & 0.17 & $0 \cdot 12$ \\
\hline Fructose-bisphosphatase & $<0.0004$ & $<0.0005$ & 0.014 & 0.024 & 0.014 & 0.030 \\
\hline Isocitrate lyase & 0.0005 & 0.00026 & 0.037 & 0.058 & 0.065 & 0.12 \\
\hline Malate dehydrogenase & 0.013 & 0.017 & 0.78 & $1 \cdot 20$ & 0.85 & $2 \cdot 12$ \\
\hline Malate synthase & $<0.01$ & $<0.01$ & 0.28 & 0.42 & 0.43 & 0.74 \\
\hline $\begin{array}{l}\text { Phosphoenolpyruvate } \\
\text { carboxykinase }\end{array}$ & 0.001 & $<0.001$ & 0.085 & 0.318 & 0.23 & 0.79 \\
\hline Pyruvate kinase & 3.0 & 3.06 & 0.925 & 0.659 & 0.73 & 0.87 \\
\hline Pyruvate carboxylase & 0.028 & 0.028 & 0.034 & 0.039 & 0.03 & 0.043 \\
\hline
\end{tabular}

Growth, $\mathrm{ATP}$ and $\mathrm{O}_{2}$ consumption after transfer of cells growing exponentially in glucose to media containing different carbon sources

To measure the adaptation of glucose-grown cells to different carbon sources, strain Y55 was grown (with two transfers) in $\mathrm{MN}+100 \mathrm{mM}$-glucose to an $A_{600}$ of 1 (exponential growth), and then cells were thoroughly washed with $\mathrm{MN}$ on membrane filters and transferred to $\mathrm{MN}+100 \mathrm{mM}$ of different carbon sources. When the new carbon source was glucose or fructose, the cells grew rapidly and without lag. The results observed with acetate, ethanol and pyruvate are shown in Fig. 1 . In $\mathrm{MN}+100 \mathrm{mM}$-acetate (Fig. $1 a, 2 a$ ) the $A_{600}$ remained constant for $70 \mathrm{~h}$ and then increased. The intracellular concentration of ATP rapidly decreased from 0.8 to less than $0.2 \mathrm{nmol} \mathrm{AM}^{-1}$ and continued to decrease for $10 \mathrm{~h}$ to immeasurably low values (less than $0.02 \mathrm{nmol} \mathrm{AM}^{-1}$ ) where it remained for $40 \mathrm{~h}$ (Fig. $2 c$ ). $\mathrm{O}_{2}$ consumption also decreased to a very low (but measurable) value where it remained (Fig. 1a). When no more ATP could be detected the viable cell titre slowly decreased (Fig. $2 b$ ). If the cells were not washed thoroughly, growth and $\mathrm{O}_{2}$ consumption (ATP was 


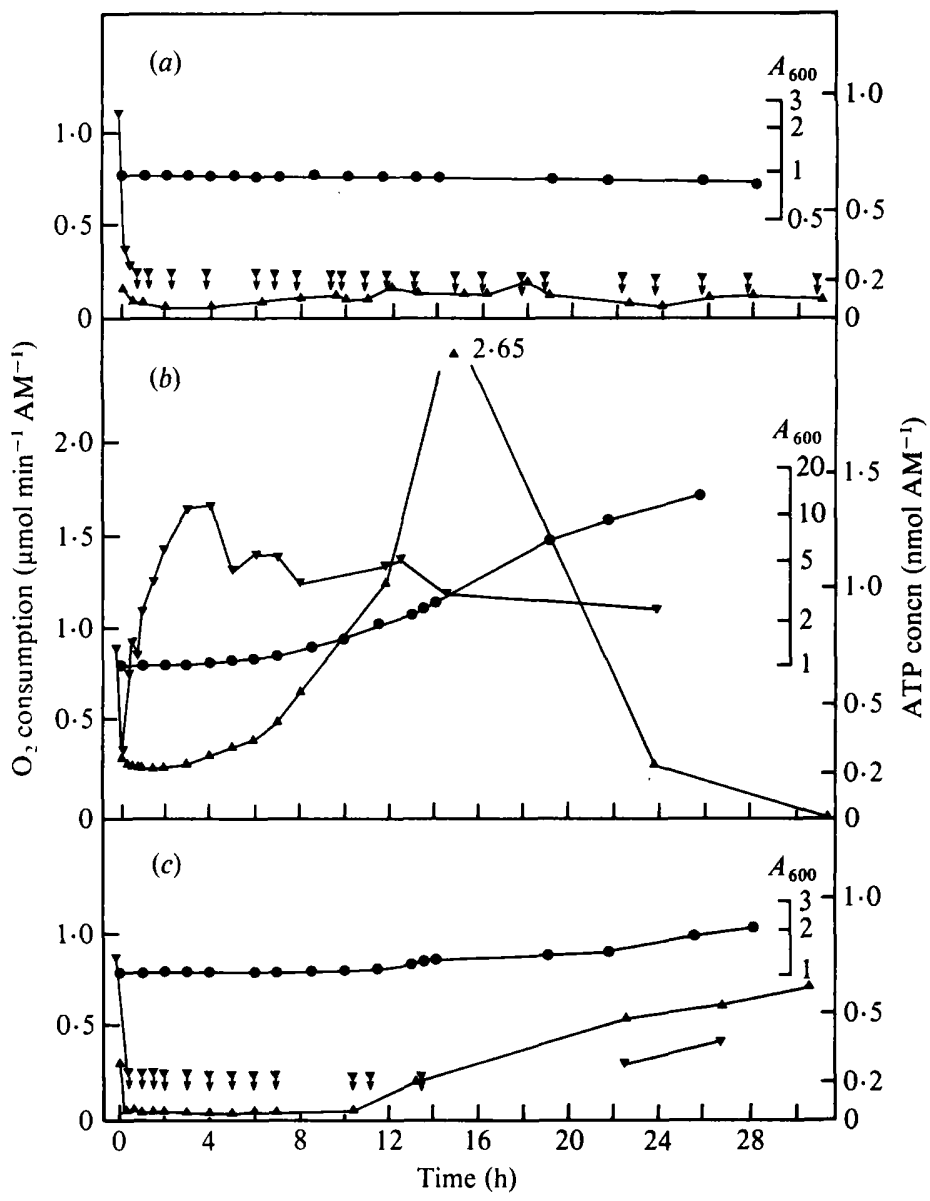

Fig. 1. Growth $\left(A_{600}\right)$, ATP concentration and oxygen consumption of strain Y55 after transfer (at an $A_{600}$ of 1) from $\mathrm{MN}+100 \mathrm{mM}$-glucose to $\mathrm{MN}+100 \mathrm{mM}$-potassium acetate $(a), \mathrm{MN}+$ $100 \mathrm{mM}$-ethanol $(b)$ and $\mathrm{MN}+100 \mathrm{mM}$-potassium pyruvate $(c)$. Washed cells were suspended in the new medium at time 0 . The data preceding time 0 represent measurements on cells in the glucose medium just before transfer. $A_{600}(\mathcal{O})$; oxygen consumption $(\boldsymbol{\Delta})$; ATP concentration $(\boldsymbol{\nabla}$; symbols with an arrow beneath signify that the ATP concentration was below the indicated level). In acetate culture no growth was observed for $72 \mathrm{~h}$.

not measured) were resumed earlier, presumably due to residual carbon sources that enabled the cells to adapt faster to grow on acetate. In control cultures without any carbon source the ATP concentration remained above $0.04 \mathrm{nmol} \mathrm{AM}^{-1}$ for $48 \mathrm{~h}$ (Fig. $2 c$ ), and more than $10 \%$ of the cells survived for $100 \mathrm{~h}$ (Fig. $2 \mathrm{~b}$ ). These results show that the presence of acetate caused a rapid consumption of ATP without enabling its regeneration.

Strikingly different results were observed when the washed cells were transferred to $\mathrm{MN}+$ 100 mM-ethanol (Fig. $1 b$ ). The $A_{600}$ began to increase within a few hours and the ATP concentration, which had decreased initially, increased again within less than $0.5 \mathrm{~h}$. Thus, soon after cell transfer to ethanol the rate of ATP consumption was essentially equal to that of ATP regeneration. The rate of $\mathrm{O}_{2}$ consumption decreased, though not as much as in the acetate culture, and remained at a low value for about $4 \mathrm{~h}$. The optimum ethanol concentration for restoration of growth (giving the shortest lag and the highest $A_{600}$ after $30 \mathrm{~h}$ ) was about $100 \mathrm{mM}$; with 50 and $250 \mathrm{mM}$-ethanol $A_{600}$ values at $30 \mathrm{~h}$ were about $20 \%$ lower, and $500 \mathrm{~mm}$-ethanol allowed only very slow growth, presumably due to the inhibitory effect of ethanol. If combinations of $100 \mathrm{~mm}$-acetate and different concentrations 

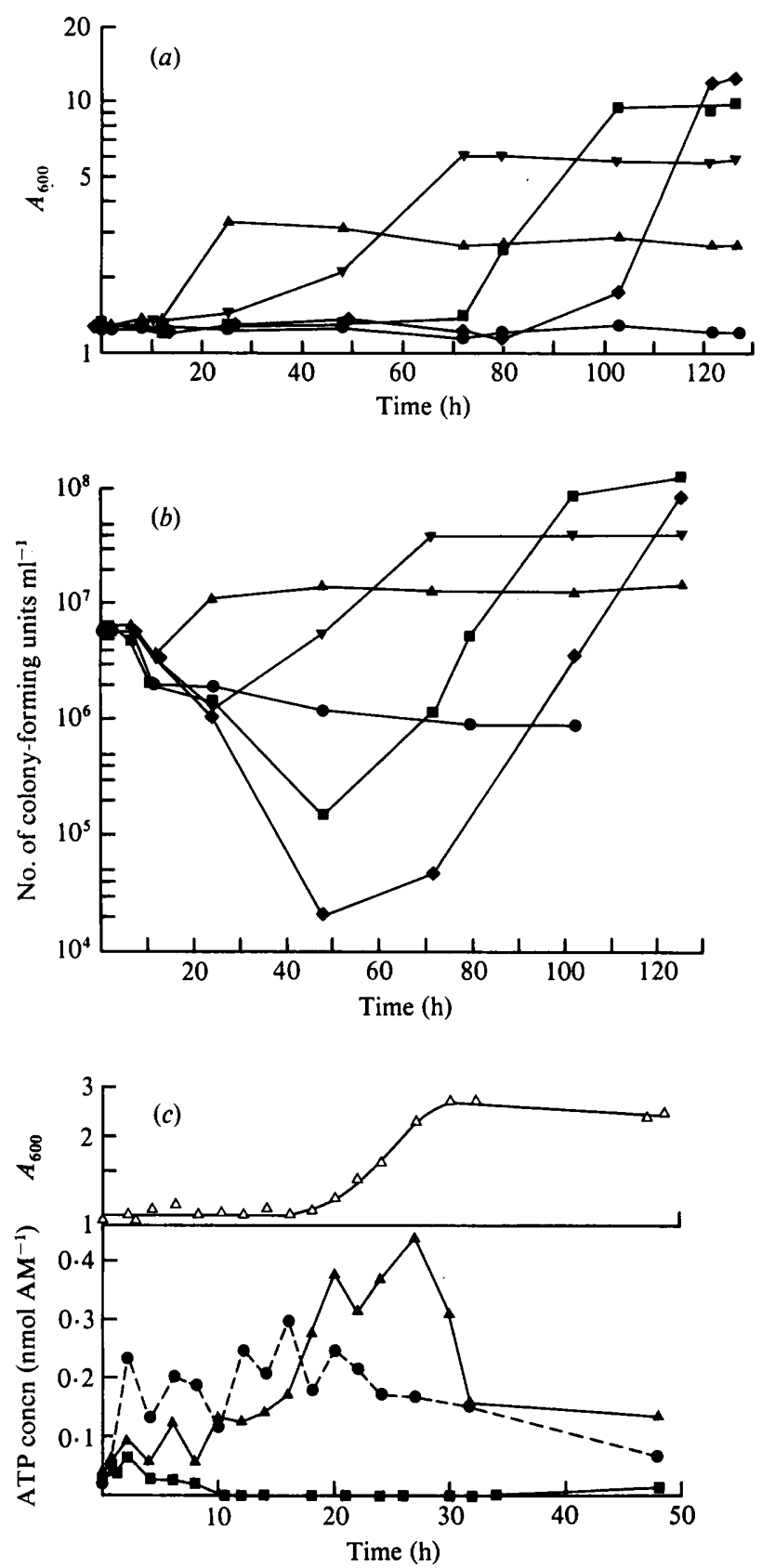

Fig. 2. Growth $\left(A_{600}\right)(a)$, survival $(b)$ and ATP concentration $(c)$ of strain Y55 after transfer (at an $A_{600}$ of 1) from $\mathrm{MN}+100 \mathrm{mM}$-glucose to $\mathrm{MN}+$ different concentrations of potassium acetate $(\mathrm{pH} 5.5): 0(\bullet), 15 \mathrm{mM}(\Delta), 50 \mathrm{mM}(\nabla), 100 \mathrm{mM}(\mathbf{\square})$ and $150 \mathrm{mM}(\bullet)$. Washed cells were suspended in the new medium at time 0 . In $(c)$, growth in $15 \mathrm{~mm}$-acetate is also shown $(\Delta)$.

of ethanol were used, the cells behaved initially as if only ethanol was present: the ethanol concentration decreased while that of acetate remained constant. When all ethanol had been used up, the cells continued to grow on the acetate.

When cells were transferred from glucose medium to $\mathrm{MN}+100 \mathrm{mM}$-pyruvate (Fig. $1 \mathrm{c}$ ), ATP and oxygen consumption remained low for about $10 \mathrm{~h}$ at which time $\mathrm{O}_{2}$ consumption 
began to increase slowly. ATP did not increase above $0.2 \mathrm{nmol} \mathrm{AM}^{-1}$ until $12 \mathrm{~h}$ later. When cells were transferred from glucose medium to $\mathrm{MN}+100 \mathrm{mM}$-dihydroxyacetone, there was no increase in $A_{600}$ and little $\mathrm{O}_{2}$ consumption $\left(0.5 \mu \mathrm{mol} \mathrm{min}{ }^{-1} \mathrm{AM}^{-1}\right)$ for $23 \mathrm{~h}$. Cells did not grow or sporulate for at least $3 \mathrm{~d}$ after transfer to $\mathrm{MN}+100 \mathrm{mM}$ L-alanine, L-aspartate, glycerol (with or without L-aspartate), L-malate or succinate.

Since the ATP pool disappeared when $100 \mathrm{~mm}$-acetate was present in the medium but not in its absence (Fig. $2 c$ ), it was possible that a lower acetate concentration would allow ATP to be maintained longer so that cells had a better chance to adapt to grow on acetate. This was found to be true: at acetate concentrations of 5, 10 (not shown) and $15 \mathrm{~mm}$ (Fig. $2 a, b)$, cells resumed growth within $24 \mathrm{~h}$ and maintained a detectable ATP concentration throughout (shown for $15 \mathrm{mM}$-acetate in Fig. 2c). At higher acetate concentrations growth resumed only much later as shown by an increase in turbidity (Fig. $2 a$ ) as well as the viable cell titre (Fig. $2 b$ ). As the normal rate of the $A_{600}$ increase was reached only slowly, a small fraction of cells apparently adapted to use acetate efficiently. Until that occurred, a fraction of the cells died (Fig. $2 b$ ). When the concentration of acetate was low, the $A_{600}$ increase eventually stopped because acetate was used up (Fig. $2 a$ ). When such adapted cells were transferred to $\mathrm{MN}+100 \mathrm{mM}$-acetate they continued to multiply.

\section{Sporulation after transfer from glucose medium to buffer plus different carbon sources}

The time dependence of sporulation, observed after transfer of cells from $\mathrm{MN}+$ glucose to M (MES buffer, pH 5.5, without yeast nitrogen base) plus $100 \mathrm{mM}$ of different carbon sources is shown in Table 1 . None of the cells sporulated within $24 \mathrm{~h}$ (in contrast to cells pregrown on acetate). As expected from the results of the growth experiments discussed above, cells sporulated earlier and more efficiently in the ethanol medium than in acetate medium. In pyruvate medium, cells sporulated later than in ethanol but earlier than in acetate. With dihydroxyacetone, cells sporulated slightly earlier than with pyruvate.

At $\mathrm{pH} 5.5$, about $15 \%$ of the acetate molecules in the medium are uncharged ( $\mathrm{p} K$ of acetate $=4 \cdot 76$, whereas all ethanol and dihydroxyacetone molecules are uncharged. As cells probably do not have an active transport mechanism for the charged acetate molecules, uncharged acetic acid molecules should pass more readily through the phospholipid bilayer of the cell membrane than charged ones. As the above results on the growth lag demonstrated, high intracellular concentrations of molecules (e.g. acetate) that have to be activated (by a reaction using ATP) before they can be further metabolized cause a too rapid drain on ATP. Therefore, a lower concentration of such molecules (acetate, dihydroxyacetone) might allow earlier sporulation. For acetate, this effect could be achieved either by decreasing the acetate concentration or by increasing the $\mathrm{pH}$ (at $\mathrm{pH} 7.0$, only $0.57 \%$ of the acetate molecules are uncharged). Figure $3(a)$ shows that at pH 5.5 an intermediate acetate concentration (about $12 \mathrm{mM}$ ) allowed optimal sporulation (measured $48 \mathrm{~h}$ after cell transfer); at a higher $\mathrm{pH}(7 \cdot 0)$ the optimal acetate concentration was higher ( 50 to $100 \mathrm{~mm}$ ). The ratio of the optimal acetate concentrations at the two $\mathrm{pH}$ values is not as large as one would have expected from the ratio of the concentration of neutral molecules at these two $\mathrm{pH}$ values. This may reflect some ability of the charged acetate molecules to enter cells or a dependence of the intracellular $\mathrm{pH}$ on the extracellular $\mathrm{pH}$, which influences acetate metabolism. To demonstrate that the charge of the acetate molecules played at least some role in the sporulation (adaptation) process, we also measured sporulation with the uncharged dihydroxyacetone; again an intermediate concentration $(30 \mathrm{mM})$ was optimal for sporulation, but in this case the same concentration optimum was observed at $\mathrm{pH} 5.5$ and $\mathrm{pH} \mathrm{7.0} \mathrm{(Fig.} 3 b$ ). In contrast to these compounds, which have to be activated before they can be metabolized, good sporulation was observed when glucose-grown cells were transferred to medium containing 20 to $150 \mathrm{mM}$-ethanol (Fig. $3 c$ ). 

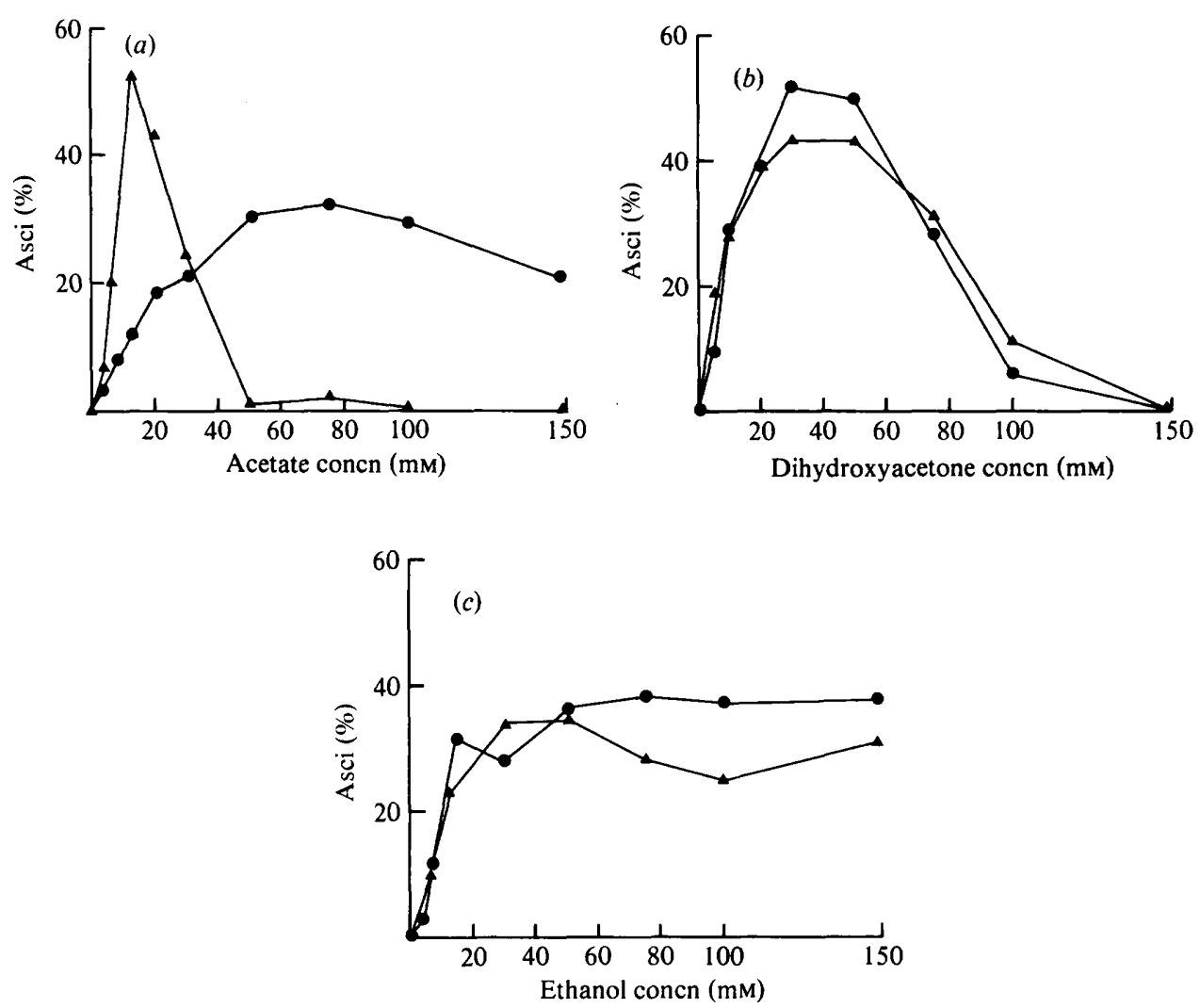

Fig. 3. Percentage of asci per cell of strain Y55 at $48 \mathrm{~h}$ after transfer (at an $A_{600}$ of 1 , time 0 ) from $\mathrm{MN}+100 \mathrm{mM}$-glucose to buffer plus various concentrations of acetate $(a)$, dihydroxyacetone $(b)$ and ethanol $(c)$. The buffers were $100 \mathrm{mM}$-MES, pH 5.5 (А) and $100 \mathrm{mM}$-TES, pH 7.0 (O).

\section{DISCUSSION}

Yeast cells transferred from a growth medium containing glucose to one containing $100 \mathrm{~mm}$ (or more) acetate as sole carbon source lost their intracellular ATP, showed a reduced ability to consume oxygen and required several days to adapt before they grew on acetate. Presumably, ATP was used (together with CoA) to convert acetate to acetyl-CoA which in turn reacted with other cell components, such as oxaloacetate (thereby regenerating CoA). But owing to the absence of one or more of the enzymes in the citric acid cycle and especially the glyoxylate shunt in glucose-grown cells (Polakis \& Bartley, 1965; Duntze et al., 1967; Haarasilta \& Oura, 1975), oxaloacetate presumably could not be regenerated so that eventually not enough compounds were available to regenerate ATP (via the electron transport system). At lower acetate concentrations ATP was not consumed as rapidly so that with $15 \mathrm{mM}$-acetate or less, cells adapted to grow on acetate in less than $24 \mathrm{~h}$.

When cells were transferred from a glucose to an ethanol growth medium, both oxygen consumption and ATP regeneration were soon restored (regardless of the presence of acetate) and they adapted to resume growth in less than $8 \mathrm{~h}$. Ethanol can be oxidized by alcohol dehydrogenase to acetaldehyde, whereby $\mathrm{NAD}^{+}$is reduced to $\mathrm{NADH}$; as the continuing oxygen consumption indicates, the NADH can be reoxidized by the electron transport system which regenerates ATP. Although growth in glucose represses the synthesis of cytochromes (Gillham, 1978), a sufficient amount of the ATP-regenerating system apparently was present in our glucose-grown cells. The balance between consumption and regeneration of ATP is 
quite precarious as can be seen by the transient decrease in ATP after transfer to the ethanol medium.

The growth response of cells transferred from glucose to pyruvate medium was intermediate between that for ethanol and acetate. Pyruvate can generate reducing compounds (NADH) via the citrate cycle, and it uses NADH for its conversion to ethanol. The combination of these reactions apparently works such that $100 \mathrm{mM}$-pyruvate can regenerate sufficient ATP to allow a slow resumption of growth about $10 \mathrm{~h}$ after cell transfer.

After transfer of glucose-grown cells to $\mathrm{MN}+100 \mathrm{mM}$-dihydroxyacetone, we observed no growth and no oxygen consumption for $23 \mathrm{~h}$. But eventually the cells adapted to grow on dihydroxyacetone. The adaptation proceeded faster in the presence of glutamate or aspartate. Whereas other strains of $S$. cerevisiae apparently grow only on the combination of dihydroxyacetone and glutamate (Miller, 1963) or glycerol and aspartate (Vezinhet et al., 1979), our strain (Y55) eventually grew with dihydroxyacetone alone almost as fast as with dihydroxyacetone plus aspartate (Table 1).

The results of sporulation in buffer plus a carbon source reflected the observations on growth. Cells sporulated well at different concentrations of ethanol, whereas they showed a sharp sporulation optimum at an intermediate concentration of acetate; this optimum concentration increased with the $\mathrm{pH}$ probably because the concentration of uncharged acetic acid molecules, which can easily pass the cell membrane, decreased. The fact that cells sporulate optimally at an intermediate acetate concentration may reflect a metabolic conflict. For sporulation, cells need an external carbon source to produce metabolites and to regenerate ATP; however, too much acetate consumes all ATP before the cellular metabolism has adapted from the glucose-repressed to the gluconeogenic condition (requiring the synthesis of glyoxylate shunt and other enzymes). Earlier reports have frequently mentioned that cells sporulate on potassium acetate better at elevated $\mathrm{pH}$ values (Fowell, 1967). As these cells were transferred to acetate towards the end of growth in a glucose medium, they may not have adapted sufficiently to gluconeogenesis. The $\mathrm{pH}$ effect may therefore have resulted from the need to keep the concentration of uncharged acetate molecules low enough so that ATP could be maintained for adaptation. In contrast, cells grown in a medium of yeast extract/peptone (YEP) plus acetate (i.e. without glucose) can sporulate almost equally well in $1 \%$ acetate at different $\mathrm{pH}$ values between 5.5 and 7.0 (McCusker \& Haber, 1977). In this case the cells are completely adapted to metabolize acetate. We have confirmed that cells adapted to grow in $\mathrm{MN}+100 \mathrm{mM}$-acetate sporulate equally well in $100 \mathrm{~mm}$-acetate buffered at $\mathrm{pH} 5.5$ or 7.0 ( 25 to $45 \%$ asci $20 \mathrm{~h}$ after cell transfer).

Metabolism of dihydroxyacetone requires an ATP-dependent phosphorylation. However, the dihydroxyacetone phosphate or glyceraldehyde 3-phosphate product can then be metabolized via the Embden-Meyerhof pathway, producing ATP directly and also indirectly via the electron transport system. As dihydroxyacetone is metabolized only slowly (doubling time $8.6 \mathrm{~h}$, see Table 1), it seems to be inefficiently transported or phosphorylated.

For practical sporulation purposes, it would seem most desirable to grow cells in a medium in which all glyoxylate bypass and gluconeogenic enzymes are derepressed. One can use an acetate-containing growth medium, such as YEP + acetate proposed by Roth \& Halvorson (1969), or a medium containing the slowly metabolizable galactose employed by Miller (1957) and Fast (1973). If glucose or fructose have to be used, one should grow cells long enough so that this carbon source has been consumed and the cells have completely adapted to the derived ethanol (Croes, 1967). One could also transfer cells to a medium containing $\mathrm{MN}$ or YEP + ethanol to which they can adapt in a reasonable time. Ethanol has the advantage that its conversion to carbonate or $\mathrm{CO}_{2}$ does not change the $\mathrm{pH}$. Glucosecontaining plates should be incubated long enough for the cells to have consumed all glucose and adapted to the derived ethanol before they are inoculated into acetate growth media; cells taken too early require a long time to adapt to acetate. 


\section{REFERENCES}

Aust, A. E. \& Suelter, C. H. (1978). Homogeneous pyruvate kinase isolated from yeast by two different methods is indistinguishable from pyruvate kinase in cell-free extract. Journal of Biological Chemistry 253, 7508-7512.

BerG, P. (1956). Acyl adenylates: an enzymatic mechanism of acetate activation. Journal of Biological Chemistry 222, 991-1013.

Bostian, K. A. \& BetTs, G. F. (1978). Rapid purification and properties of potassium-activated aldehyde dehydrogenase from Saccharomyces cerevisiae. Biochemical Journal 173, 773-786.

Ciriacy, M. (1975). Genetics of alcohol dehydrogenase in Saccharomyces cerevisiae. I. Isolation and genetic analysis of adh mutants. Mutation Research 29, 327-333.

Croes, A. F. (1967). Induction of meiosis in yeast. II. Metabolic factors leading to meiosis. Planta 76, 227-237.

Diesterhaft, M. D. \& Freese, E. (1973). Role of pyruvate carboxylase, phosphoenolpyruvate carboxykinase, and malic enzyme during growth and sporulation of Bacillus subtilis. Journal of Biological Chemistry 248, 6062-6070.

Dixon, G. H. \& Kornberg, H. L. (1959). Assay methods for key enzymes of the glyoxylate cycle. Biochemical Journal 72, 3P.

Duntze, W., Atzpodien, W. \& Holzer, H. (1967). Glucose-dependent enzyme activities in different yeast species. Archiv für Mikrobiologie 58, 296-301.

EsTABROOK, R. W. (1967). Mitochondrial respiratory control and the polarographic measurement of ADP :O ratios. Methods in Enzymology 10, 41-47.

FAST, D. (1973). Sporulation synchrony of Saccharomyces cerevisiae grown in various carbon sources. Journal of Bacteriology 116, 925-930.

Ferguson, J. J., JR, BOLL, M. \& HOLZER, H. (1967). Yeast malate dehydrogenase: enzyme inactivation in catabolite repression. European Journal of Biochemistry 1, 21-25.

Fowell, R. R. (1967). Factors controlling the sporulation of yeasts. II. The sporulation phase. Journal of Applied Bacteriology 30, 450-474.

FoY, J. J. \& BhatTACHARJEE, J. K. (1977). Gluconeogenesis in Saccharomyces cerevisiae: determination of fructose-1,6-bisphosphatase activity in cells grown in the presence of glycolytic carbon sources. Journal of Bacteriology 129, 978-982.

FriedemanN, T. E. \& HaNGen, G. E. (1943). II. The determination of keto acids in blood and urine. Journal of Biological Chemistry 147, 415-442.

Gillham, N. W. (1978). Organelle Heredity, pp. 123146. New York: Raven Press.

HAARAsIlta, S. \& OURA, E. (1975). On the activity and regulation of anaplerotic and gluconeogenic enzymes during the growth process of Baker's yeast. The biphasic growth. European Journal of Biochemistry 52, 1-7.
HANSEN, R. J., Hinze, H. \& Holzer, H. (1976). Assay of phosphoenolpyruvate carboxykinase in crude yeast extracts. Analytical Biochemistry 74, 576-584.

Holz, G. \& Bergmeyer, H. U. (1974). Determination with acetate kinase and hydroxylamine. In Methods of Enzymatic Analysis, vol. 3, pp. 15281532. Edited by H. U. Bergmeyer. New York \& London: Academic Press.

Kielley, W. W. (1963). Preparation and assay of phosphorylating submitochondrial particles: sonicated mitochondria. Methods in Enzymology 6, 272-277.

Levin, B. C. \& Freese, E. (1977). Comparison of the effects of two lipophilic acids, hexachlorophene and decanoate on Bacillus subtilis. Antimicrobial Agents and Chemotherapy 12, 357-367.

Maxon, W. D. \& Johnson, M. J. (1953). Aeration studies on propagation of Baker's yeast. Industrial and Engineering Chemistry 45, 2554-2560.

MCCusker, J. H. \& HABER, J. E. (1977). Efficient sporulation of yeast in media buffered near pH 6 . Journal of Bacteriology 132, 180-185.

MiLler, J. J. (1957). The metabolism of yeast sporulation. II. Stimulation and inhibition by monosaccharides. Canadian Journal of Microbiology 3, 81-90.

Miller, J. J. (1963). The metabolism of yeast sporulation. V. Stimulation and inhibition of sporulation and growth by nitrogen compounds. Canadian Journal of Microbiology 9, 259-277.

MILlER, J. J. \& HOFFMANN-OSTENHOF, O. (1964). Spore formation and germination in Saccharomyces. Zeitschrift für allgemeine Mikrobiologie 4, 273-294.

Polakis, E. S. \& Bartiey, W. (1965). Changes in the enzyme activities of Saccharomyces cerevisiae during aerobic growth on different carbon sources. Biochemical Journal 97, 284-297.

RACKER, E. (1950). Crystalline alcohol dehydrogenase from Baker's yeast. Journal of Biological Chemistry 184, 313-319.

Roth, R. \& Halvorson, H. O. (1969). Sporulation of yeast harvested during logarithmic growth. Journal of Bacteriology 98, 831-832.

Ruiz-Amil, M., DE TORRontegui, G., Palacian, E., Catalina, L. \& Losada, M. (1965). Properties and function of yeast pyruvate carboxylase. Journal of Biological Chemistry 240, 3485-3492.

VezinheT, F., KinNaiRd, J. H. \& DAwes, I. W. (1979). The physiology of mutants derepressed for sporulation in Saccharomyces cerevisiae. Journal of General Microbiology 115, 391-402.

WIrT, I. (1974). Determination with alcohol dehydrogenase and 3-acetylpyridine analogue of NAD (APAD). In Methods of Enzymatic Analysis, vol. 3, pp. 1502-1505. Edited by H. U. Bergmeyer. New York \& London: Academic Press. 